\title{
1,3-Dipolar character of 2-vinyl quinazoline 3-oxides; first and second generation cycloaddition products
}

\section{Frances Heaney, ${ }^{* a}$ Elaine Lawless, ${ }^{a}{ }^{\text {Mary Mahon, }},{ }^{b}$ Patrick McArdle ${ }^{c}$ and Desmond Cunningham ${ }^{c}$}

\author{
Received 17th February 2006, Accepted 13th April 2006 \\ First published as an Advance Article on the web 11th May 2006 \\ DOI: 10.1039/b602423h
}

The reaction between the heteroaromatic $N$-oxides $1 \mathbf{1 a}, \mathbf{1 b}$ and $\mathbf{1 c}$ with dimethyl acetylenedicarboxylate or methyl propiolate furnishes 1,3-benzodiazepines, the products of ring transformations of primarily formed cycloadducts. The structures of $\mathbf{8 a}$ and 10a have been confirmed by X-ray crystallographic analysis. The aldonitrone $1 \mathbf{c}$ also reacts with $N$-methylmaleimide and with phenyl vinyl sulfone to furnish the first examples of primary cycloaddition products from quinazoline 3-oxides.

\section{Introduction}

Nitrone cycloaddition chemistry is a key tool for the synthesis of natural products and biologically important synthetic compounds. Developments in this area continue apace with annulation to cyclic nitrones being particularly useful. The variety of nitrone and dipolarophilic components, as well as the complex rearrangement pathways available to primary cycloadducts, renders the reaction attractive for the building of a wide range of heterocyclic systems not readily obtained by other means. ${ }^{1}$ Whilst 1,3-dipolar cycloadditions to a range of heteroaromatic $N$-oxides have received varying amounts of attention, additions to quinazoline derivatives have had scarce mention in the literature. A single paper dating from 1972 describes the addition of acetylenedicarboxylate esters to quinazoline 3-oxides $2{ }^{2}$ two further papers report the addition of the same dipolarophiles to quinazoline 3-methylides. ${ }^{3,4}$ In all cases the isolated products were the products of ring transformation reactions on the primary cycloadducts. Thus, addition to the quinazoline 3-oxide $\mathbf{2}$, studied in benzene with (m)ethanol as cosolvent, afforded, after purification on basic alumina, the phenyl acrylates $3(13-21 \%)$ and the benzodiazepines $4(5-14 \%)$ together with smaller amounts of other products.

\section{Results and discussions}

The quinazoline 3-oxide $\mathbf{1 b}$ failed to be trapped by alkene dipolarophiles, dimethyl fumarate $\left(18 \mathrm{~h}\right.$, toluene, $\left.110{ }^{\circ} \mathrm{C}\right)$ or (m)ethyl acrylate even following heating in the absence of a solvent, and in each case the starting material was returned unchanged. Neither could any cycloaddition products be found following heating of a solution of $\mathbf{1 b}$ with $N$-methyl maleimide (2 equivalents) to reflux in any of THF, MeCN or toluene. Attempts to coerce reactivity by heating $\mathbf{1 b}$ with $N$-phenyl maleimide (5 equivalents) in boiling xylene flagged the thermal instability of 1b. Thus, separation of the reaction mixture provided two new products. On the basis of their NMR spectral data alone, these compounds are tentatively assigned as the deoxygenated nitrone

${ }^{a}$ Department of Chemistry, National University of Ireland, Maynooth, Ireland

${ }^{b}$ Department of Chemistry, University of Bath, Bath, U.K. BA2 7 AY

'Department of Chemistry, National University of Ireland, Galway, Ireland
$5(13 \%)$ and the addition product $6(13 \%)$. The latter may arise from an ene reaction between $N$-phenylmaleimide and 4methylquinazoline 5. In particular, in the ${ }^{1} \mathrm{H}$ NMR spectrum of 5 the $\mathrm{C}-4$ methyl protons resonate at $2.98 \mathrm{ppm},\left(\mathrm{CDCl}_{3}\right)$. The downfield shift in this resonance with respect to the corresponding protons in $\mathbf{1 b}\left(2.40 \mathrm{ppm}, \mathrm{C}_{6} \mathrm{D}_{6}\right)^{5 a}$ and the reported resonance of the methyl protons of 4-methylquinazoline at $2.94 \mathrm{ppm}\left(\mathrm{CDCl}_{3}\right)^{5 b}$ is in keeping with the suggested structure. The diastereomeric protons, $\mathrm{H}_{\mathrm{a}}$ and $\mathrm{H}_{\mathrm{a}^{\prime}}$ of $\mathbf{6}$ resonate as doublets of doublets (3.09 and $3.21 \mathrm{ppm}$ ). Literature support for these proposals lies with the known deoxygenation of aromatic $N$-oxides in boiling xylene ${ }^{6}$ and with the reported reaction between 2-methylquinoxalines and maleimides, furnishing, by way of their enamine tautomers, products parallel to $6^{7}$

The reaction between the 4-methyl-2-styrylquinazoline 3-oxide 1a and dimethyl acetylenedicarboxylate (2 equivalents) reached completion after $16 \mathrm{~h}$ heating in refluxing anhydrous THF. ${ }^{1} \mathrm{H}$ NMR spectral analysis of the crude reaction mixture suggested the formation of a single product in almost quantitative yield, yet purification by flash column chromatography on silica gel furnished a disappointingly small product yield (36\%). Analogous findings were made following the reaction of the allyl substituted dipole $\mathbf{1 b}$ under the same conditions and a single product was isolated in $34 \%$ yield from a crude reaction mixture which appeared to contain no other materials. Independent stirring of the crude products from either reaction in a slurry of silica gel in the column eluting solvent $(6 \mathrm{~h}, \mathrm{rt})$ suggested very little change in composition, accordingly, we have no good explanation for the poor isolated yield of these adducts.

The ${ }^{1} \mathrm{H}$ NMR spectra of the isolated adducts were not inconsistent with the structure of the proposed primary cycloaddition products $\mathbf{7 a} / \mathbf{b}$, however, following crystallisation from diethyl ether-hexane the product structure was unambiguously identified by X-ray crystallographic analysis as having the $5 H-1,3-$ benzodiazepine framework 8 (Fig. 1). Thermal lability of $\Delta^{4}$ isoxazolines is well known ${ }^{8}$ and it has previously been demonstrated that the products isolated from the reaction between dialkyl acetylenedicarboxylates and related heteroaromatic $N$-oxides viz. pyrimidine $N$-oxides, ${ }^{9}$ quinoline $N$-oxides, ${ }^{10}$ isoquinoline $N$ oxides, ${ }^{11}$ and phthalazine $N$-oxides ${ }^{12}$ arise by ring transformation of initially formed 1,3-dipolar cycloaddition products. Only in the case of the quinoxaline 4-oxides $\mathbf{9}$ has the primary cycloadduct 


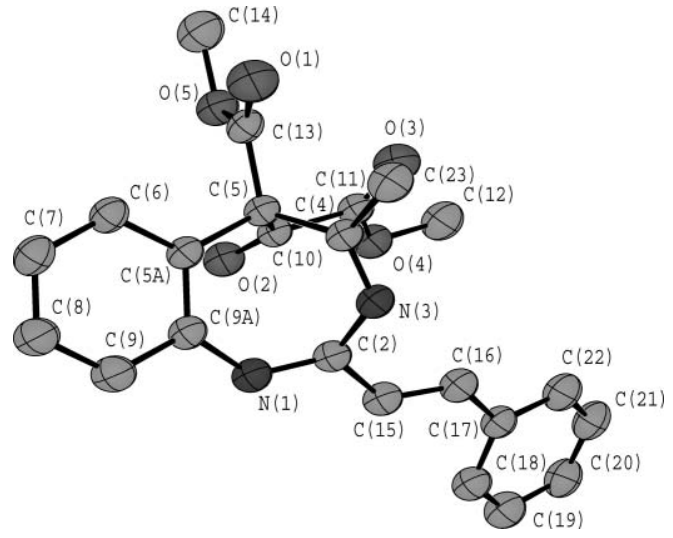

Fig. 1 X-Ray projection of 8a. Ellipsoids represent $40 \%$ probability levels.

been characterised.$^{13}$ The mechanism speculated for the formation of $\mathbf{8 a} / \mathbf{b}$ is based on the assumption that the diazepine skeleton arises from $7 \mathbf{a} / \mathbf{b}$ by way of a cyclopropyl intermediate as shown in Fig. 2. Interestingly, in the ${ }^{1} \mathrm{H}$ NMR spectrum of both adducts $\mathbf{8 a} / \mathbf{b}$ all resonance signals were sharply resolved with the exception of the signal representing the imino methyl protons (2.56 and
2.47 ppm respectively) suggesting a degree of conformational mobility for the 7-membered ring at $\mathrm{rt}$.

The $5 H$-1,3-benzodiazepine bicyclic skeleton of $\mathbf{8}$ is rare in the literature; Strauss' access to this skeleton is demonstrated in the formation of $\mathbf{4},{ }^{2}$ Malamidou-Xenikaki et al. have shown two further routes viz. reductive cyclisation of the isoxazoline formed by nitrile oxide cycloaddition to 2,3,3-trimethyl-3 $H$-indole or intramolecular cyclisation between appropriately positioned amidinium and carbonyl functionalities. ${ }^{14}$ The product of ring expansion of 2-quinolinyl imidogen is characterised as the $2 \mathrm{H}$ tautomer of the same bicyclic skeleton. ${ }^{15}$ The determination of $\mathbf{8 a}$ represents the first X-ray crystal structure of this bicyclic skeleton.

In an effort to improve the isolated yields of $\mathbf{8 a} / \mathbf{b}$ purification of the reaction products on alumina was considered; control experiments to establish the stability of the 1,3-benzodiazepines on alumina supports indicated decomposition to complex mixtures following stirring in a slurry of either acidic or basic alumina and clean conversion to one new product on neutral alumina. The reactions between dimethyl acetylenedicarboxylate and the quinazoline 3 -oxides $\mathbf{1 a} / \mathbf{b}$ were repeated and the products were isolated following chromatography over neutral alumina.

The product arising from reaction of $\mathbf{1 a}$ formed cubic crystals from ether-hexane and an X-ray crystal structure analysis<smiles>[Y]C=Cc1nc2ccccc2c([R])[n+]1[O-]</smiles>

$$
\begin{gathered}
1 \\
\text { a. } R=M e, R^{1}=P h \\
\text { b. } R=M e, R^{1}=M e \\
\text { c. } R=H, R^{1}=P h
\end{gathered}
$$<smiles>Cc1nc2ccccc2c(-c2ccccc2)[n+]1[O-]</smiles>
2

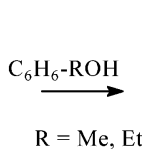

$\mathrm{R}=\mathrm{Me}, \mathrm{Et}$<smiles>[R]OC(=O)/C(=C(\N)c1ccccc1)c1ccccc1N</smiles>

3<smiles>[R]OC(=O)C1(c2ccccc2)C(c2ccccc2)=NC(C)=Nc2cccnc21</smiles><smiles>[R20]C(=O)C1=C(c2ccccc2)N([TlH])C(C)=Nc2ccccc21</smiles>
$3 H-4$<smiles>[CH]=C</smiles><smiles>Cc1nc(/C=C/c2ccccc2)nc2ccccc12</smiles><smiles>CC1C(=O)N(c2ccccc2)C(=O)C1Cc1nc(/C=C/c2ccccc2)nc2ccccc12</smiles>

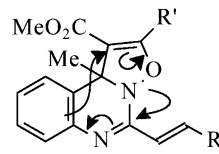

7<smiles>[R]OC(=O)C1=C(I)N=C(C)N(C)c2ccccc21</smiles>

6

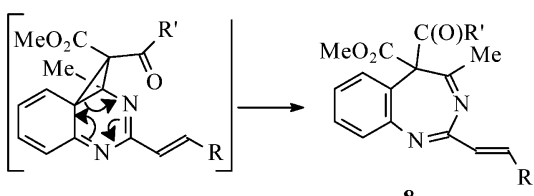

a. $\mathrm{R}=\mathrm{Ph} ; \mathrm{R}^{\prime}=\mathrm{CO}_{2} \mathrm{Me}$

b. $\mathrm{R}=\mathrm{Me} ; \mathrm{R}^{\prime}=\mathrm{CO}_{2} \mathrm{Me}$

c. $\mathrm{R}=\mathrm{Ph} ; \mathrm{R}^{\prime}=\mathrm{H}$

d. $\mathrm{R}=\mathrm{Me} ; \mathrm{R}^{\prime}=\mathrm{H}$

Fig. 2 Proposed mechanism for the rearrangement of the tricycles 7 to the benzodiazepines 8. 
determined it to be the 5-methoxycarbonyl-5H-1,3-benzodiazepine $5 \mathrm{H}-\mathbf{1 0 a}(30 \%)$ (Fig. 3). Its origin from 8a, outlined in Fig. 4, is presumed to involve hydrolysis of the $\alpha$-ketocarbomethoxy group on the chromatographic support. Ready hydrolysis of dialkyl $\alpha$-oxosuccinates to methyl acetates has previously been noted. ${ }^{16}$ Whilst the X-ray data of $5 H$-10a shows prototropy is suppressed in the crystalline state rapid prototropic equilibrium is evident in solution. In the ${ }^{1} \mathrm{H}$ NMR spectrum of $\mathbf{1 0 a}(\mathrm{rt})$ the methyl protons of the imine functionality appear at 2.39 (major) and $2.32 \mathrm{ppm}$ (minor tautomer) whilst the resonance of the methoxy protons is seen at 3.47 (major) and $3.74 \mathrm{ppm}$ (minor tautomer). A sharp signal at $4.65 \mathrm{ppm}$ is suggestive of a $\mathrm{CH}$ rather than an $\mathrm{NH}$ resonance and thus $5 \mathrm{H-10a}$ is believed to be the major component in solution. This is in keeping with Stauss' estimation that the $5 \mathrm{H}$-isomer represents at least $90 \%$ of the tautomeric mixture of the 2,4,5-trisubstituted benzodiazepine $4{ }^{2}$ Variable temperature ${ }^{1} \mathrm{H}$ NMR spectra indicate an enhanced preference for the $5 \mathrm{H}$ tautomer as the probe temperature is decreased from $0{ }^{\circ} \mathrm{C}$ to $-25^{\circ} \mathrm{C}$ to $-50{ }^{\circ} \mathrm{C}$.

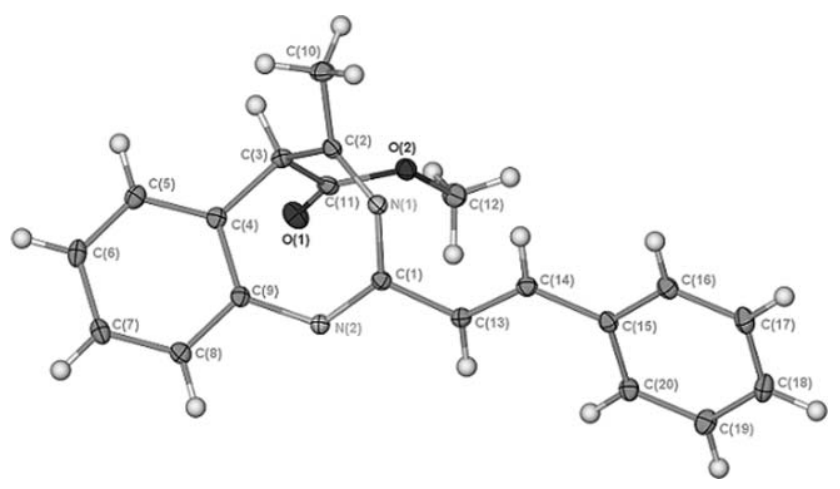

Fig. 3 X-Ray projection of 10a. Ellipsoids represent $40 \%$ probability levels.
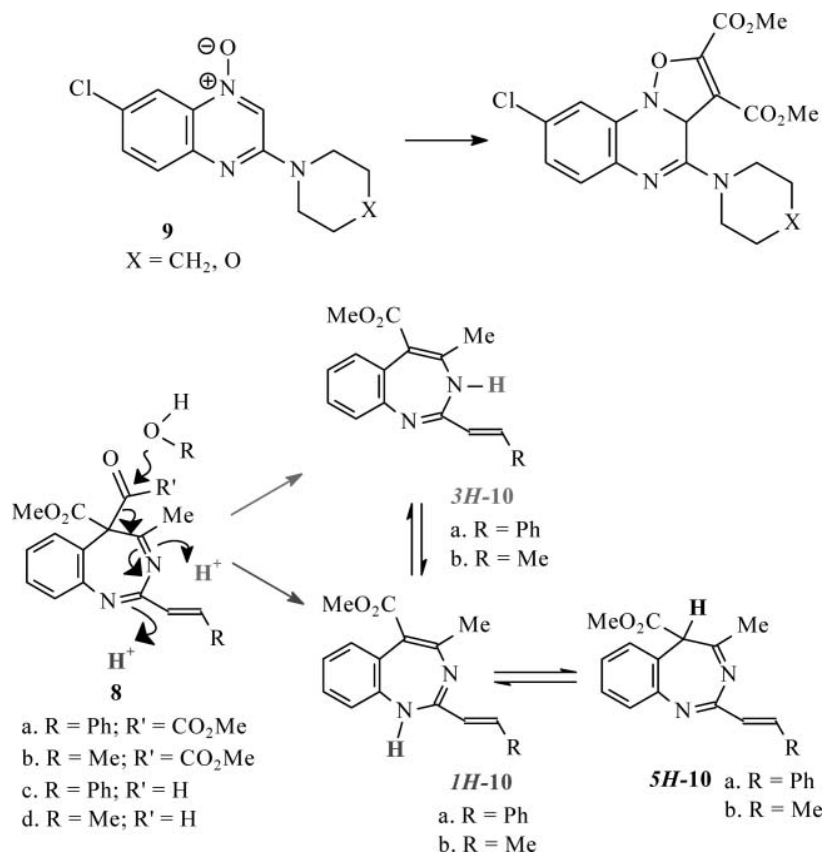

Fig. 4 Proposed mechanism for the hydrolysis of $\mathbf{8}$ and the tautomeric equilibria of the resulting benzodiazepines $\mathbf{1 0}$.
The relationship between $5 H$-10a and the possible minor tautomers, $1 \mathrm{H}$ - and $3 H-10$ a is shown in Fig. 4. It is difficult to unambiguously assign the structure of the minor tautomer, there are conflicting literature reports on the dominance of $1 \mathrm{H}$ - over $3 H$-tautomers for $N$-unsubstiuted benzodiazepines. One group has suggested that $1 \mathrm{H}$-isomers are unstable and isomerise rapidly to the $3 H$-isomers, ${ }^{17,18}$ yet another group characterise related compounds as $1 H$-isomers. ${ }^{19,20}$ Thermal 1,3-sigmatropic $\mathrm{H}$-shifts are disallowed processes, however, isomerisation between $1 \mathrm{H}$ and $3 \mathrm{H}$-isomers could be possible through intermolecular proton exchange between neighbouring hydrogen bonded benzodiazepine molecules as is presented as an argument for the exchange of $\mathrm{H}$ between N-1 and N-3 of monocyclic diazepines. ${ }^{21}$ On the basis of these literature reports and the spectral data available for 10 it is impossible to conclude unambiguously whether the $N$ unsubstituted tautomer is the $1 H$ - or the $3 H$-isomer.

The product isolated from the reaction of $\mathbf{1 b}$ with dimethyl acetylenedicarboxylate following chromatographic separation on alumina displays analogous spectral characteristics and consequently is formulated as $\mathbf{1 0 b}(32 \%)$.

Silica gel and alumina are not inert chromatography supports for compounds with a variety of structural features, and in particular, imine-enamine isomerisation on these supports is known. Isolation of hydrolysis products from attempted purification of enamines on silica gel has also been observed. ${ }^{22}$ Our observation that hydrolysis of $\mathbf{8 a} / \mathbf{b}$ to $\mathbf{1 0 a} / \mathbf{b}$ is facile on alumina but not on silica gel is suggestive of a greater availability of surface hydroxyl groups on the former.

Reaction between the dipoles $\mathbf{1 a} / \mathbf{b}$ and methyl propiolate (4 equivalents) reached completion after $48 \mathrm{~h}$ stirring in boiling anhydrous THF. Inspection of the ${ }^{1} \mathrm{H}$ NMR spectral data of the crude reaction mixtures in each case suggested conversion to one new product with a high degree of selectivity. Significantly, for each dipole chromatographic separation of the reaction mixture on either silica gel or on neutral alumina afforded only one major product, a species which was not present in the crude samples. The ${ }^{1} \mathrm{H}$ NMR spectra of the isolated adducts were identical to those of 10a and $10 \mathrm{~b}$ respectively. Isolated yields from chromatography on $\mathrm{Al}_{2} \mathrm{O}_{3}$ were superior to those resulting from purification on $\mathrm{SiO}_{2}$ when much decomposed material was found.

It is speculated that $\mathbf{1 0 a} / \mathbf{b}$ form from $\mathbf{1 a} / \mathbf{b}$ and methyl propiolate by way of the benzodiazepines $\mathbf{8 c} / \mathbf{d}$. The regiochemical preference for the addition of methyl propiolate to nitrones is for the formation of 4 -substituted isoxazoline rings, ${ }^{23}$ thus $\mathbf{7 c / d}$ are proposed as the primary cycloaddition products. Ring expansion to the benzodiazepines $\mathbf{8 c} / \mathbf{d}$ followed by attack on the methyl formylacetate moiety and elimination of $\mathrm{HCO}_{2} \mathrm{H}$ furnishes $\mathbf{1 0 a} / \mathbf{b}$. Loss of a formyl group from a formylacetate moiety has been proposed previously. ${ }^{8}$

The observation that $\mathbf{1 0 a} / \mathbf{b}$ result from chromatography over either $\mathrm{SiO}_{2}$ or $\mathrm{Al}_{2} \mathrm{O}_{3}$ reflects a more facile attack on the formyl group of $\mathbf{8 c} / \mathbf{d}$ with respect to the $\alpha$-oxoester group of $\mathbf{8 a} / \mathbf{b}$.

Whilst the isoxazolo[2,3-c]quinazoline tricycle has previously been formed from a cyclocondensation reaction of 4-methylthioquinazoline 3-oxides with active methylene compounds, ${ }^{24}$ aldonitrones from the quinazoline 3-oxide series have never before been the subject of a dipolar cycloaddition study. The reduced steric demand about the nitrone moiety encouraged us in persuit of cycloadducts from trapping of the aldonitrone 1c with olefinic 


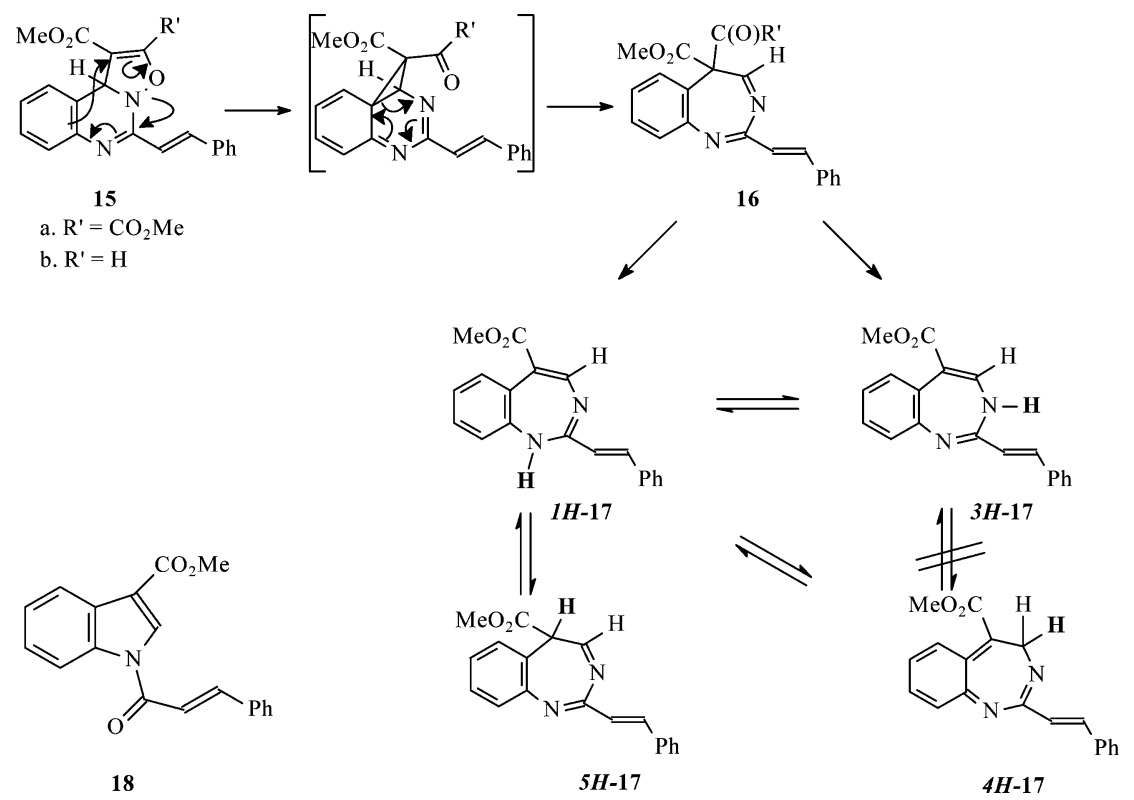

Fig. 5 Proposed mechanism for the rearrangement of the tricycles $\mathbf{1 5}$ to the tautomeric benzodiazepines $\mathbf{1 7}$.

dipolarophiles, viz. phenyl vinyl sulfone or $N$-methyl maleimide. The reaction with maleimide was complete in $30 \mathrm{~min}$ (rt, THF). Purification of the reaction products furnished the diastereomeric cycloadducts $11(17 \%)$ and $\mathbf{1 2}(54 \%)$, NOE difference spectroscopy experiments confirmed the relative stereochemistry. Thus for $\mathbf{1 2}$ irradiation of $\mathrm{H}$-a resulted in a $6 \%$ enhancement on the resonance signal representing $\mathrm{H}-\mathrm{b}$ establishing $\mathbf{1 2}$ as the product of an endocycloaddition. A $1.5 \%$ enhancement between the corresponding protons of adduct $\mathbf{1 1}$ confirms it to have resulted from an exoalignment of the reactants in the transition state leading to cycloadduct formation.

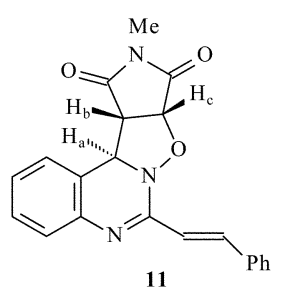

11
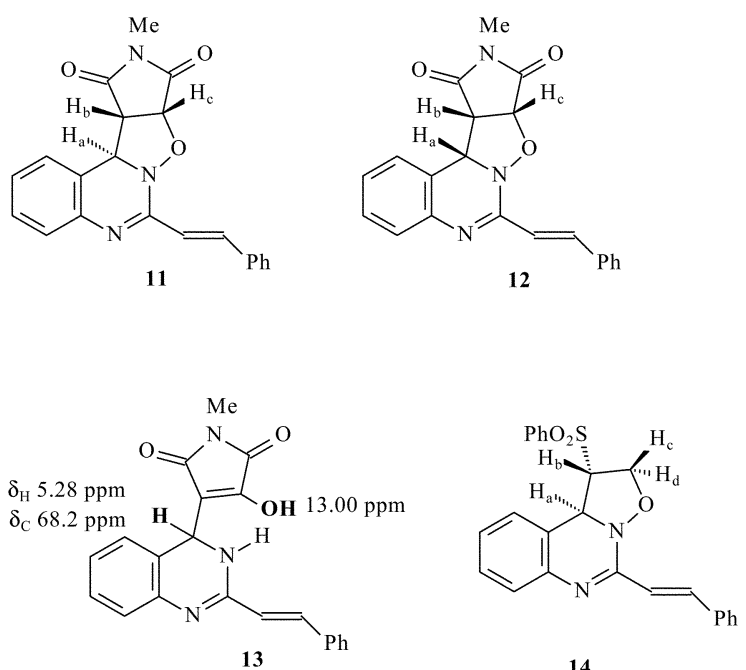

14

The major isomer 12 was found to be unstable on standing in solution at room temperature, the rearranged product is tentatively assigned as the ring opened adduct 13, key NMR spectral data in support of this structure are shown in the drawing.

The trapping of $\mathbf{1} \mathbf{c}$ with phenyl vinyl sulfone progressed more slowly having reached $50 \%$ conversion of nitrone after $24 \mathrm{~h}$ heating in boiling THF. The adduct $\mathbf{1 4}$ was isolated as a single regioisomer.
A comparison of the NOEDS data for $\mathbf{1 4}$ with that obtained for the isomeric adducts $\mathbf{1 1}$ and $\mathbf{1 2}$ permits the interpretation that a $2 \%$ enhancement on the signal representing $\mathrm{H}-\mathrm{b}$ following irradiation of $\mathrm{H}$-a is in keeping with $\mathbf{1 4}$ being the product of an exo-addition.

Cycloaddition of aldonitrone 1c to dimethyl acetylenedicarboxylate was rapid and after 15 min (THF, rt) the reaction had reached completion. Following chromatography on either $\mathrm{Al}_{2} \mathrm{O}_{3}$ or $\mathrm{SiO}_{2}$ one product was isolated in 7 and $20 \%$ yield respectively. ${ }^{1} \mathrm{H}$ NMR spectroscopy suggests the product to be a 1,3-benzodiazepine, either $1 H$ - or $3 H$-17. There are three defining resonance signals in the spectrum of a fresh sample of this sample $\left(\mathrm{CDCl}_{3}\right)$. A singlet at $5.50 \mathrm{ppm}$ represents the enamine proton, $4-\mathrm{H}$, a singlet at $3.79 \mathrm{ppm}$ represents the methoxy protons and a downfield resonance at $\sim 12.80 \mathrm{ppm}$ is characteristic of a strongly $\mathrm{H}$-bonded NH proton. The mechanistic origin of $1 \mathrm{H}-/ 3 \mathrm{H}-17$ likely parallels that of $\mathbf{1 0 a} / \mathbf{b}$ with an initial cycloaddition, yielding 15a, preceding ring expansion to the benzodiazepine 16a. The aldimine functionality apparently facilitates hydrolysis since $10 \mathbf{a} / \mathbf{b}$ is isolable from $\mathrm{SiO}_{2}$ whilst 16a undergoes hydrolysis resulting in the generation of $1 H-/ 3 H-17$ (Fig. 5).

After a few minutes in solution the presence of an additional tautomer is evident with further signals appearing, at 4.35 and $3.76 \mathrm{ppm}$, in the ${ }^{1} \mathrm{H}$ NMR spectrum of 17. A DEPT- $135{ }^{13} \mathrm{C}$ NMR spectrum of the equilibrating mixture indicates the presence of one methylene group, at $42.0 \mathrm{ppm}$. The tautomeric structure is therefore the $\mathrm{C}-4$ unsubstituted structure, $4 H-17$. The formation of the $4 H$-tautomer, for which no corresponding tautomer presents from the keto series, is likely a consequence of the enhanced stabilisation of $4 \mathrm{H}-17$ due to the more highly substituted double bond. Since thermal 1,7-sigmatropic hydrogen shifts are not possible for cyclic systems it seems likely that $4 \mathrm{H-17}$ must arise from $1 H-17$. The ratio of tautomers in the equilibrium mixture at $\mathrm{rt}$ is $\sim 3: 1$ in $\mathrm{CDCl}_{3}$ and $\sim 3: 2$ in $d_{6}$-DMSO, in favour of the $1 H$ - over the $3 H$-tautomer. Variable temperature ${ }^{1} \mathrm{H}$ NMR spectra $\left(\mathrm{CDCl}_{3}\right)$ indicate minimal influence of temperature on the tautomeric ratio over the temperature range $25^{\circ} \mathrm{C}$ to $-50{ }^{\circ} \mathrm{C}$. 
The aldonitrone 15a also reacted with methyl propiolate. Two products were isolated. The compound with the lower $R_{\mathrm{f}}$ value, isolated in $9 \%$ yield, was identified as $1 H-/ 3 H-17$ and its solution tautomer $4 \mathrm{H}$-17. Higher running material, also a white solid and also obtained in low yield $(5 \%)$ was unambiguously identified as the indole 18 following X-ray crystallographic analysis, Fig. 6. The structure had two molecules per asymmetric unit. Rearrangement of benzodiazepines to indoles has a literature precedent, with reactions being described under conditions of thermal or acid activation. ${ }^{25}$

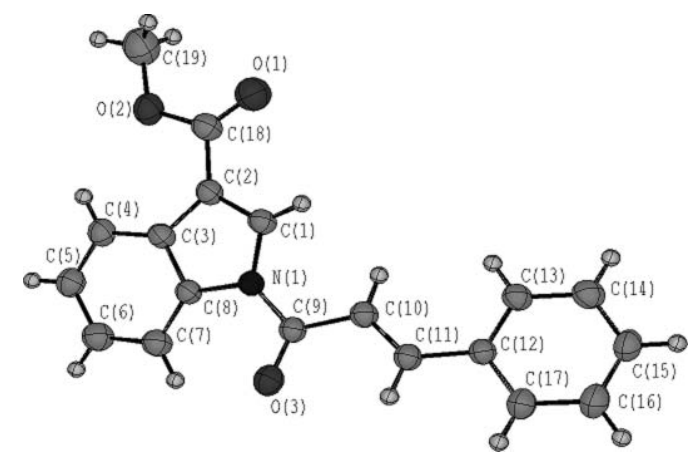

Fig. 6 X-Ray projection of 18. Ellipsoids represent $40 \%$ probability levels.

\section{Conclusions}

The investigations into the 1,3-dipolar character of aldo- and ketonitrones of the quinazoline 3-oxide series have yielded many interesting results in terms of the nature, and the chemical and the structural stability of the products isolated. With the ketonitrones 1a/b cycloaddition to olefinic dipolarophiles is not observed; that this failure to react is due to a steric impediment, is supported by the observation that the aldonitrone 1c can be trapped both by phenyl vinyl sulfone and by $N$-methylmaleimide. In all cases 1,3-benzodiazepines were found as the isolated products from the trapping of 1 with acetylenic dipolarophiles implying a facile rearrangement of the primarily formed cycloadducts. We have noted that the crude reaction products were not always stable to purification by column chromatography and that depending on the nature of the $\mathrm{C}-4$ and $\mathrm{C}-5$ substituents on the diazepine ring hydrolysis was observed during separation on either or both $\mathrm{SiO}_{2}$ or $\mathrm{Al}_{2} \mathrm{O}_{3}$. Solution phase tautomerism is evident in the benzodiazepines $\mathbf{1 0}$ and $\mathbf{1 7}$ where the hetero-ring is not fully substituted. The X-ray analysis of $10 \mathrm{a}$ indicates the presence of only the $5 \mathrm{H}$-tautomer in the solid state whilst the $1 H / 3 H$-tautomer is also present in solution. The equilibration between the tautomers of $\mathbf{1 7}$ involves the $1 H / 3 H$ - with the $4 H$-isomer, the apparent shift in tautomeric preference is in deference to the greater stability associated with the more highly substituted double bonds in the latter.

\section{Experimental}

Melting points were determined on a Stuart Scientific (Bibby) melting point apparatus and are uncorrected. Elemental analyses were performed on a CE-440 analytical instrument. ${ }^{1} \mathrm{H}$ and ${ }^{13} \mathrm{C}$ NMR spectra were recorded using a Bruker NMR spectrometer operating at $300 \mathrm{MHz}$ for ${ }^{1} \mathrm{H}$ and $75 \mathrm{MHz}$ for ${ }^{13} \mathrm{C}$ nuclei. Data were recorded at probe temperatures with, unless otherwise stated, tetramethylsilane as the internal reference and deuterochloroform as the solvent; $J$ values are given in Hertz. Flash column chromatography was carried out on silica gel $60(0.040-0.063 \mathrm{~nm})$ purchased from Merck. Analytical TLC plates were purchased from Merck, aluninium backed and coated with silica gel 60 $\mathrm{F}_{254}$ indicator. Samples were located by UV illumination using a portable UVtec lamp ( $\lambda, 254 \mathrm{~nm}$ ) or by the use of iodine staining. Infrared spectra were recorded on a Perkin Elmer 2000 FT-IR instrument, samples were prepared as $\mathrm{KBr}$ discs. The quinazoline 3-oxides 1 were prepared as described elsewhere. ${ }^{5 a}$

\section{Reaction between 1a and $N$-phenylmaleimide in boiling xylene-proposed formation of 5 and 6}

A solution of 4-methyl-2-[(1E)-prop-1-enyl]quinazoline-3-oxide $1 \mathrm{a}(0.10 \mathrm{~g}, 0.49 \mathrm{mmol})$ and $N$-phenylmaleimide $(0.42 \mathrm{~g}, 2.45 \mathrm{mmol})$ was allowed to heat at reflux in xylene $\left(13 \mathrm{~cm}^{3}\right)$ for $24 \mathrm{~h}$. The solvent was removed under reduced pressure and the crude mixture was purified by flash column chromatography $\left(\mathrm{SiO}_{2}\right.$, hexane-ether 7 : 3 ) affording two products. The first product is tentatively identified as the addition product $6 . \delta_{\mathrm{H}} 1.88(3 \mathrm{H}, \mathrm{dd}, J=6.9,1.8, \mathrm{CH}=\mathrm{CH}-$ $\left.\mathrm{CH}_{3}\right) ; 3.09\left(1 \mathrm{H}, \mathrm{dd}, \mathrm{J}=18.2,5.9, \mathrm{CH}\right.$ of $\left.\mathrm{CH}_{2}-\mathrm{C}=\mathrm{O}\right) ; 3.21(1 \mathrm{H}$, $\mathrm{dd}, J=18.2,9.3, \mathrm{CH}$ of $\left.\mathrm{CH}_{2}-\mathrm{C}=\mathrm{O}\right) ; 3.66(1 \mathrm{H}, \mathrm{m}, \mathrm{CH}) ; 3.93(2 \mathrm{H}$, $\left.\mathrm{m}, \mathrm{CH}_{2}\right) ; 6.65\left(1 \mathrm{H}, \mathrm{m}, \mathrm{CH}=\mathrm{CH}-\mathrm{CH}_{3}\right) ; 7.12(1 \mathrm{H}, \mathrm{dq}, J=15.5$, 6.9, $\left.\mathrm{CH}=\mathrm{CH}-\mathrm{CH}_{3}\right) ; 7.49(6 \mathrm{H}, \mathrm{m}, \mathrm{ArCH}) ; 7.84(1 \mathrm{H}, \mathrm{m}, \mathrm{ArCH})$; $7.95(1 \mathrm{H}, \mathrm{m}, \mathrm{ArCH}) ; 8.04(1 \mathrm{H}, \mathrm{m}, \mathrm{ArCH})$. The second product is identified as the deoxygenated nitrone, 5. $\delta_{\mathrm{H}} 2.98\left(3 \mathrm{H}, \mathrm{s}, \mathrm{CH}_{3}\right)$; $7.38(4 \mathrm{H}, \mathrm{m}, 3 \times \mathrm{ArCH}$ and $1 \times \mathrm{CH}=\mathrm{CH}-\mathrm{Ph}) ; 7.56(1 \mathrm{H}, \mathrm{m}$, $\mathrm{ArCH}) ; 7.65(2 \mathrm{H}, \mathrm{m}, \mathrm{ArCH}) ; 7.84(1 \mathrm{H}, \mathrm{m}, \mathrm{ArCH}) ; 7.98(1 \mathrm{H}$, $\mathrm{d}, J=8.2, \mathrm{ArCH}) ; 8.06(1 \mathrm{H}, \mathrm{m}, \mathrm{ArCH}) ; 8.16(1 \mathrm{H}, \mathrm{d}, J=$ $15.9, \mathrm{CH}=\mathrm{CH}-\mathrm{Ph}) . \delta_{\mathrm{C}} 20.9\left(\mathrm{CH}_{3}\right) ; 121.8(\mathrm{C} 4 \mathrm{a}) ; 124.1(\mathrm{ArCH})$; $125.8 ; 126.6 ; 127.2 ; 127.7 ; 127.6(\mathrm{ArCH}$ and $\mathrm{CH}=\mathrm{CH}-\mathrm{Ph}) ; 132.6$ $(\mathrm{ArCH}) ; 135.3(\mathrm{ArC}) ; 137.2(\mathrm{CH}=\mathrm{CH}-\mathrm{Ph}) ; 149.2(\mathrm{C} 8 \mathrm{a}) ; 159.4$ (C4); 166.9 (C2).

\section{Methyl 5-[methoxy(oxo)acetyl]-4-methyl-2-[(E)-2-phenylvinyl]- $5 H$-1,3-benzadiazepine-5-carboxylate, 8 a}

From reaction between $1 \mathrm{a}$ and dimethyl acetylenedicarboxylate followed by purification on $\mathrm{SiO}_{2}$. A solution of 4-methyl-2-[(E)2-phenylvinyl]quinazoline-3-oxide, 1a, $(0.20 \mathrm{~g}, 0.76 \mathrm{mmol})$ and dimethyl acetylenedicarboxylate $(0.22 \mathrm{~g}, 1.52 \mathrm{mmol})$ was heated at reflux in dry THF $\left(10 \mathrm{~cm}^{3}\right)$ overnight. The solvent was removed under reduced pressure and the crude oil was purified by flash column chromatography over silica gel (hexane-ether $6: 5$ ). The title product was isolated as a yellow solid $(0.10 \mathrm{~g}, 36 \%), \mathrm{mp} 114$ $117^{\circ} \mathrm{C}$ (hexane-ether). $\left(\mathrm{C}_{23} \mathrm{H}_{20} \mathrm{~N}_{2} \mathrm{O}_{5}\right.$ requires: $\mathrm{C}, 68.31 ; \mathrm{H}, 4.98 ; \mathrm{N}$, 6.92. Found: C, 68.26; H, 5.17; N, 6.61\%.) $\delta_{\mathrm{H}} 2.56\left(3 \mathrm{H}\right.$, br s, $\left.\mathrm{CH}_{3}\right)$; $3.56\left(3 \mathrm{H}, \mathrm{s}, \mathrm{OCH}_{3}\right) ; 3.89\left(3 \mathrm{H}, \mathrm{s}, \mathrm{OCH}_{3}\right) ; 6.77(1 \mathrm{H}, \mathrm{d}, J=16.0$, $\mathrm{CH}=\mathrm{CHPh}) ; 7.44(10 \mathrm{H}, \mathrm{m}, 9 \times \mathrm{ArH}, \mathrm{CH}=\mathrm{CHPh}) . \delta_{C} 25.1\left(\mathrm{CH}_{3}\right)$; $53.2\left(\mathrm{OCH}_{3}\right) ; 53.5\left(\mathrm{OCH}_{3}\right) ; 71.1(\mathrm{C} 5) ; 122.1(\mathrm{C} 5 \mathrm{a}) ; 126.5(\mathrm{ArCH})$; $126.9(\mathrm{CH}=\mathrm{CHPh}) ; 127.7,127.8,128.8,129.3,129.7,135.6,(9 \times$ $\mathrm{ArCH}) ; 138.8(\mathrm{CH}=\mathrm{CHPh}) ; 144.2(\mathrm{C} 9 \mathrm{a}) ; 159.4\left(\mathrm{COCO}_{2} \mathrm{CH}_{3}\right)$; $163.1\left(\mathrm{CO}_{2} \mathrm{CH}_{3}\right) ; 166.1(\mathrm{C} 2, \mathrm{C} 4) ; 181.9\left(\mathrm{COCO}_{2} \mathrm{CH}_{3}\right)$. IR: $v=$ $1767.5,1743.8,1726.5(\mathrm{CO})$.

X-Ray crystal determination of 8a $\uparrow$. The structure was solved by direct methods, SHELXS-97, ${ }^{26}$ and refined by full matrix

$\dagger$ CCDC reference numbers 298840, 602119 and 602120. For crystallographic data in CIF or other electronic format see DOI: 10.1039/b602423h 
Table 1 Crystal data and structure refinement for $\mathbf{8 a}$
Empirical formula

Temperature

Wavelength

Crystal system

Space group

Unit cell dimensions

Volume

$Z$

Absorption coefficient

$F(000)$

Crystal size

Theta range for data collection

Index ranges

Reflections collected

Independent reflections

Reflections observed $(>2 \sigma)$

Data completeness

Absorption correction

Refinement method

Data/restraints/parameters

Goodness-of-fit on $F^{2}$

Final $R$ indices $[I>2 \sigma(I)]$

$R$ indices (all data)

Largest diff. peak and hole
Identification code

Formula weight

Density (calculated)

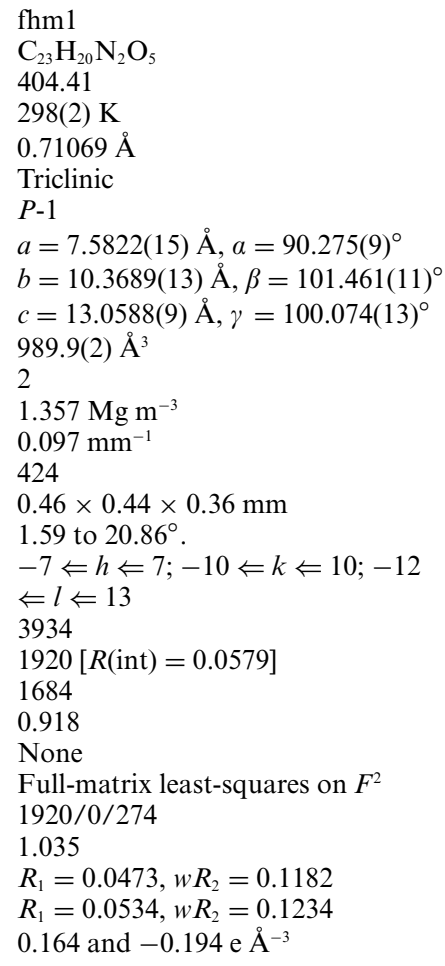

fhm1

$\mathrm{C}_{23} \mathrm{H}_{20} \mathrm{~N}_{2} \mathrm{O}_{5}$

404.41

298(2) K

$0.71069 \AA$

Triclinic

$P-1$

$a=7.5822(15) \AA, \alpha=90.275(9)^{\circ}$

$b=10.3689(13) \AA, \beta=101.461(11)^{\circ}$

$c=13.0588(9) \AA, \gamma=100.074(13)^{\circ}$

$989.9(2) \AA^{3}$

2

$1.357 \mathrm{Mg} \mathrm{m}^{-3}$

$0.097 \mathrm{~mm}^{-1}$

424

$0.46 \times 0.44 \times 0.36 \mathrm{~mm}$

1.59 to $20.86^{\circ}$.

$-7 \Leftarrow h \Leftarrow 7 ;-10 \Leftarrow k \Leftarrow 10 ;-12$

$\Leftarrow l \Leftarrow 13$

3934

$1920[R($ int $)=0.0579]$

1684

0.918

None

Full-matrix least-squares on $F^{2}$

$1920 / 0 / 274$

1.035

$R_{1}=0.0473, w R_{2}=0.1182$

$R_{1}=0.0534, w R_{2}=0.1234$

0.164 and -0.194 e $\AA^{-3}$

$R$ indices; $R_{1}=\left[\Sigma\left\|F_{\mathrm{o}}|-| F_{\mathrm{c}}\right\|\right] / \Sigma\left|F_{\mathrm{o}}\right|$ (based on $\left.F\right), w R_{2}=\left[\left[\Sigma_{w}\left(\mid F_{\mathrm{o}}{ }^{2}-\right.\right.\right.$ $\left.\left.\left.F_{\mathrm{c}}{ }^{2} \mid\right)^{2}\right] /\left[\Sigma_{w}\left(F_{\mathrm{o}}{ }^{2}\right)^{2}\right]\right]^{1 / 2}$ (based on $\left.F^{2}\right) . w=1 /\left[\left(\sigma F_{\mathrm{o}}\right)^{2}+(0.0571 \times P)^{2}+\right.$ $0.22 \times P]$. Goodness-of-fit $=\left[\Sigma_{w}\left(F_{\mathrm{o}}{ }^{2}-F_{\mathrm{c}}{ }^{2}\right)^{2} /(\text { Nobs }-N \text { parameters })\right]^{1 / 2}$.

least squares using SHELXL-97. ${ }^{27}$ SHELX operations were automated using OSCAIL which was also used to obtain the drawings. ${ }^{28}$ The XDS program was used for data reduction and the data was corrected for Lorentz and polarization effects but not for absorption..$^{29}$ Hydrogen atoms were included in calculated positions with thermal parameters $30 \%$ larger than the atom to which they were attached. The non-hydrogen atoms were refined anisotropically. All calculations were performed on a Pentium PC. Details of the data collection, solutions, and refinements are given in Table 1.

Methyl 4-methyl-2-[(E)-2-phenylvinyl]-5H-1,3-benzodiazepine-5carboxylate, 10a

(i) From the reaction between 1a and dimethyl acetylenedicarboxylate followed by purification on $\mathbf{A l}_{2} \mathbf{O}_{3}$. The reaction was repeated as above on a scale of 1.5 and the crude oil was purified by column chromatography over neutral alumina, (hexane-ether $6: 5)$. The title compound was isolated as a yellow solid $(0.12 \mathrm{~g}$, $30 \%$ ), mp $134-137^{\circ} \mathrm{C}$ (hexane-ether). $\left(\mathrm{C}_{20} \mathrm{H}_{18} \mathrm{~N}_{2} \mathrm{O}_{2}\right.$ requires: $\mathrm{C}$, $75.45 ; \mathrm{H}, 5.69 ; \mathrm{N}, 8.79$. Found: C, 75.27; $\mathrm{H}, 5.79 ; \mathrm{N}, 8.79 \%) . \delta_{\mathrm{H}}$ $2.32\left(0.6 \mathrm{H}, \mathrm{br} \mathrm{s}, \mathrm{CH}_{3}\right.$ taut $) ; 2.39\left(2.4 \mathrm{H}, \mathrm{s}, \mathrm{CH}_{3}\right.$ taut $) ; 3.47(2.4 \mathrm{H}, \mathrm{s}$, $\mathrm{OCH}_{3}$ taut $) ; 3.74\left(0.6 \mathrm{H}\right.$, br s, $\mathrm{OCH}_{3}$ taut $) ; 4.65(0.80 \mathrm{H}, \mathrm{s}, \mathrm{CH}$ taut); $6.84(1 \mathrm{H}, \mathrm{d}, J=16.0, \mathrm{CH}=\mathrm{CHPh}) ; 7.88(10 \mathrm{H}, \mathrm{m}, 9 \times$ $\mathrm{ArH}, \mathrm{CH}=\mathrm{CHPh}) . \delta_{\mathrm{C}} 26.9\left(\mathrm{CH}_{3}\right) ; 52.6\left(\mathrm{OCH}_{3}\right) ; 57.1(\mathrm{C} 5) ; 124.8$ $(\mathrm{C} 5 \mathrm{a}) ; 127.0(\mathrm{CH}=\mathrm{CHPh}) ; 127.3,127.7,127.8,128.7,128.8,129.0$, $129.3(9 \times \mathrm{ArCH}) ; 136.0(\mathrm{ArC}) ; 138.5(\mathrm{CH}=\mathrm{CHPh}) ; 144.4(\mathrm{C} 4 \mathrm{a})$; $159.4(\mathrm{C}=\mathrm{O}) ; 165.7(\mathrm{C} 2) ; 167.5(\mathrm{C} 4) . \mathrm{IR}: v=3055.9(\mathrm{NH}) ; 2954.7$ $(\mathrm{CH}=\mathrm{CH}) ; 1732.6\left(\mathrm{CO}_{2} \mathrm{CH}_{3}\right)$.

(ii) From the reaction between $1 \mathrm{a}$ and methyl propiolate followed by purification on either (a) $\mathrm{SiO}_{2}$ or (b) neutral $\mathrm{Al}_{2} \mathbf{O}_{3}$. A solution of $1 \mathrm{a}(0.20 \mathrm{~g}, 0.76 \mathrm{mmol})$ and methyl propiolate $(0.26 \mathrm{~g}, 3.04$ moles) was heated at reflux in dry THF $\left(15 \mathrm{~cm}^{3}\right)$ overnight. The solvent was removed under reduced pressure and the crude oil was purified by column chromatography according to either (a) or (b) below.

(a) Purification over silica gel. The product 10a, eluted from hexane-ether $(6: 5)$ as the mobile phase, was obtained as a yellow solid $(0.06 \mathrm{~g}, 23 \%)$.

(b) Purification over neutral alumina. The product 10a, eluted using hexane-ether $(6: 5)$, was obtained as a yellow solid $(0.19 \mathrm{~g}$, $60 \%)$.

X-Ray crystal determination of 10a $\dagger$. Single crystals were analyzed using a Nonius Kappa CCD diffractometer. Details of the data collection, solutions, and refinements are given in Table 2. The model was solved and subsequently refined using full-matrix least squares in SHELXL-97 ${ }^{30}$

\section{Methyl 5-[methoxy(oxo)acetyl]-4-methyl-2-[(1E)-prop-1-enyl]-5 $H$ - 1,3-benzodiazepine-5-carboxylate, $8 \mathrm{~b}$}

From the reaction between $1 \mathrm{~b}$ and dimethyl acetylenedicarboxylate followed by purification on $\mathbf{S i O}_{2}$. A solution of 4-methyl2-[(1E)-prop-1-enyl]quinazoline-3-oxide, $1 \mathbf{b},(0.16 \mathrm{~g}, 0.77 \mathrm{mmol})$, and dimethyl acetylenedicarboxylate $(0.22 \mathrm{~g}, 1.54 \mathrm{mmol})$ was heated at reflux in dry THF $\left(10 \mathrm{~cm}^{3}\right)$ overnight. The solvent was removed under reduced pressure and the crude oil was purified by flash column chromatography $\left(\mathrm{SiO}_{2}\right.$, hexane-ether, $1: 1)$. The pure product was isolated as a yellow solid $(0.09 \mathrm{~g}$,

Table 2 Crystal data and structure refinement for 10a

Identification code
Empirical formula
Formula weight
Temperature
Wavelength
Crystal system
Space group
Unit cell dimensions

Volume

$Z$

Density (calculated)

Absorption coefficient $F(000)$

Crystal size

Theta range for data collection Index ranges

Reflections collected Independent reflections Reflections observed $(>2 \sigma)$

Data completeness

Absorption correction

Refinement method

Data/restraints/parameters

Goodness-of-fit on $F^{2}$

Final $R$ indices $[I>2 \sigma(I)]$

$R$ indices (all data)

Largest diff. peak and hole h04pma2

$\mathrm{C}_{20} \mathrm{H}_{18} \mathrm{~N}_{2} \mathrm{O}_{2}$

318.36

150(2) K

$0.71073 \AA$

Triclinic

$P-1$

$a=7.4920(1) \AA, a=73.159(1)^{\circ}$

$b=9.0450(2) \AA, \beta=73.945(1)^{\circ}$

$c=13.5630(4) \AA, \gamma=70.568(1)^{\circ}$

$812.88(3) \AA^{3}$

2

$1.301 \mathrm{Mg} \mathrm{m}^{-3}$

$0.085 \mathrm{~mm}^{-1}$

336

$0.50 \times 0.50 \times 0.50 \mathrm{~mm}$

3.62 to $27.57^{\circ}$

$-9 \Leftarrow h \Leftarrow 9 ;-11 \Leftarrow k \Leftarrow 11$;

$-17 \Leftarrow l \Leftarrow 17$

14444

$3688[R($ int $)=0.0283]$

3052

0.980

None

Full-matrix least-squares on $F^{2}$

$3688 / 0 / 220$

1.031

$R^{1}=0.0381, w R_{2}=0.0922$

$R^{1}=0.0488, w R_{2}=0.0982$

0.226 and $-0.192{\mathrm{e} \AA^{-3}}^{-3}$ 
$34 \%$ ), mp 100-103 ${ }^{\circ} \mathrm{C}$ (hexane-ether). $\left(\mathrm{C}_{18} \mathrm{H}_{18} \mathrm{~N}_{2} \mathrm{O}_{5}\right.$ requires: $\mathrm{C}$, 63.15; H, 5.30; N, 8.19. Found: C, 63.14; H, 5.25; N, 8.39\%.) $\delta_{\mathrm{H}} 1.91\left(3 \mathrm{H}, \mathrm{d}, J=6.4, \mathrm{CH}=\mathrm{CHCH}_{3}\right) ; 2.47\left(3 \mathrm{H}, \mathrm{s}, \mathrm{CH}_{3}\right)$; $3.71\left(3 \mathrm{H}, \mathrm{s}, \mathrm{OCH}_{3}\right) ; 3.88\left(3 \mathrm{H}, \mathrm{s}, \mathrm{OCH}_{3}\right) ; 6.11(1 \mathrm{H}, \mathrm{d}, J=$ 15.6, $\left.\mathrm{CH}=\mathrm{CHCH}_{3}\right) ; 6.69\left(1 \mathrm{H}, \mathrm{m}, \mathrm{CH}=\mathrm{CHCH}_{3}\right) ; 7.41(4 \mathrm{H}, \mathrm{m}$, $\mathrm{ArH}) . \delta_{\mathrm{C}} 18.4\left(\mathrm{CH}=\mathrm{CHCH}_{3}\right) ; 25.0\left(\mathrm{~N}=\mathrm{CCH}_{3}\right) ; 53.2\left(\mathrm{OCH}_{3}\right)$; $53.5\left(\mathrm{OCH}_{3}\right) ; 70.8$ (C5); 122.0 (C5a); $126.4(\mathrm{ArCH}) ; 127.5$ $(\mathrm{ArCH}) ; 128.7(\mathrm{ArCH}) ; 129.6(\mathrm{ArCH}) ; 130.5\left(\mathrm{CH}=\mathrm{CHCH}_{3}\right)$; $138.1\left(\mathrm{CH}=\mathrm{CHCH}_{3}\right) ; 144.1(\mathrm{C} 9 \mathrm{a}) ; 159.4\left(\mathrm{COCO}_{2} \mathrm{CH}_{3}\right) ; 161.2$ $\left(\mathrm{CO}_{2} \mathrm{CH}_{3}\right) ; 166.1(\mathrm{C} 2, \mathrm{C} 4) ; 181.7\left(\mathrm{COCO}_{2} \mathrm{CH}_{3}\right)$. IR: $v=1758.8$, $1740.8,1732.1(\mathrm{C}=\mathrm{O})$.

\section{Methyl 4-methyl-2-[(1E)-prop-1-enyl]-5H-1,3-benzodiazepine-5- carboxylate, $10 \mathrm{~b}$}

(i) From the reaction between $1 \mathrm{~b}$ and dimethyl acetylenedicarboxylate followed by purification on $\mathrm{Al}_{2} \mathbf{O}_{3}$. A solution of $\mathbf{1 b}$ $(0.20 \mathrm{~g}, 0.99 \mathrm{mmol})$, and dimethyl acetylenedicarboxylate $(0.28 \mathrm{~g}$, $1.99 \mathrm{mmol})$ was heated at reflux in dry THF $\left(10 \mathrm{~cm}^{3}\right)$ overnight. The solvent was removed under reduced pressure and the crude oil was purified by column chromatography over neutral alunina (hexane-ether, $7: 3$ ). A single product was isolated as a yellow solid (0.09 g, 32\%), mp 73-77 ${ }^{\circ} \mathrm{C}$ (hexane-ether). $\left(\mathrm{C}_{15} \mathrm{H}_{16} \mathrm{~N}_{2} \mathrm{O}_{2} \cdot 2 \mathrm{H}_{2} \mathrm{O}\right.$ requires: $\mathrm{C}, 61.63$; $\mathrm{H}, 6.80$; N, 9.50. Found: $\mathrm{C}, 61.29: \mathrm{H}, 6.33$; $\mathrm{N}, 9.00 \%$.) $\delta_{\mathrm{H}} 1.93\left(3 \mathrm{H}, \mathrm{dd}, J=6.9,1.5, \mathrm{CH}_{3}\right) ; 2.25(0.5 \mathrm{H}$, br s, $\mathrm{CH}_{3}$ taut); 2.32 (2.5H, s, $\mathrm{CH}_{3}$ taut); 3.50 (2.5H, s, $\mathrm{OCH}_{3}$ taut); $3.85\left(0.5 \mathrm{H}\right.$, br s, $\mathrm{OCH}_{3}$ taut $) ; 4.59(0.82 \mathrm{H}, \mathrm{s}, \mathrm{CH}$ taut $) ; 6.17$ $\left(0.82 \mathrm{H}, \mathrm{m}, \mathrm{CH}=\mathrm{CHCH}_{3}\right.$ taut $) ; 6.21\left(0.18 \mathrm{H}, \mathrm{m}, \mathrm{CH}=\mathrm{CHCH}_{3}\right.$ taut); $6.77\left(1 \mathrm{H}, \mathrm{dq}, J=15.5,6.9, \mathrm{CH}=\mathrm{CHCH}_{3}\right) ; 7.17(1 \mathrm{H}, \mathrm{d}$, $J=7.5, \mathrm{ArH}) ; 7.29(1 \mathrm{H}, \mathrm{m}, \mathrm{ArH}) ; 7.42(2 \mathrm{H}, \mathrm{m}, \mathrm{ArH}) . \delta_{\mathrm{C}} 18.4$ $\left(\mathrm{CH}=\mathrm{CHCH}_{3}\right) ; 26.8\left(\mathrm{CH}_{3}\right) ; 52.5\left(\mathrm{OCH}_{3}\right) ; 57.5(\mathrm{C} 5) ; 124.9(\mathrm{C} 5 \mathrm{a})$; $126.9(\mathrm{ArCH}) ; 127.6(\mathrm{ArCH}) ; 128.7(\mathrm{ArCH}) ; 129.2(\mathrm{ArCH}) ; 130.5$ $\left(\mathrm{CH}=\mathrm{CHCH}_{3}\right) ; 137.7\left(\mathrm{CH}=\mathrm{CHCH}_{3}\right) ; 144.3(\mathrm{C} 9 \mathrm{a}) ; 159.2(\mathrm{C}=\mathrm{O})$; $165.2(\mathrm{C} 2) ; 167.7(\mathrm{C} 4)$. IR: $v=3426.7(\mathrm{NH}) ; 1731.4(\mathrm{C}=\mathrm{O})$.

(ii) From the reaction between $1 \mathrm{~b}$ and methyl propiolate followed by purification on either (a) $\mathrm{SiO}_{2}$ or (b) neutral $\mathrm{Al}_{2} \mathbf{O}_{3}$. A solution of $1 \mathbf{b}(0.20 \mathrm{~g}, 0.99 \mathrm{mmol})$ and methyl propiolate $(0.33 \mathrm{~g}, 3.99 \mathrm{mmol})$ was heated at reflux in dry THF $\left(14 \mathrm{~cm}^{3}\right)$ for $48 \mathrm{~h}$. The solvent was removed under reduced pressure and the crude oil was purified by column chromatography according to either (a) or (b) below.

(a) Purification over silica gel. The product $\mathbf{1 0 b}$, eluted from hexane-ether $(6: 5)$ as the mobile phase, was obtained as a yellow solid $(0.02 \mathrm{~g}, 7 \%)$.

(b) Purification over neutral alumina. The product $\mathbf{1 0 b}$, eluted using hexane-ether $(6: 5)$ as the mobile phase, was obtained as a yellow solid $(0.16 \mathrm{~g}, 54 \%)$.

\section{0-Methyl-6-[(E)-2-phenylethenyl]-11a,11b-}

dihydropyrrolo $\left[3^{\prime}, 4^{\prime}: 4,5\right]$ isoxazolo[2,3-c]quinazoline-

9,11(8a $H, 10 H)$-diones 11 and 12 and 3-hydroxy-1-methyl-4$\{$ 2-[(E)-2-phenylethenyl]-3,4-dihydro-4-quinazolinyl $\}-1 H$-pyrrole2,5-dione 13

A solution of $\mathbf{1 b}$ and $N$-methylmaleimide $(0.22 \mathrm{~g}, 1.62 \mathrm{mmol})$ in dry THF $\left(25 \mathrm{~cm}^{3}\right)$ was allowed to stir at $\mathrm{rt}$ for $30 \mathrm{~min}$. The solvent was removed under reduced pressure and the crude mixture was purified by flash column chromatography $\left(\mathrm{SiO}_{2}\right.$, hexane-ether, $1: 1)$.
$12(0.49 \mathrm{~g}, 17 \%)$, a yellow solid, $\mathrm{mp} 133-134{ }^{\circ} \mathrm{C}$ (hexane-ether). $\left(\mathrm{C}_{21} \mathrm{H}_{17} \mathrm{~N}_{3} \mathrm{O}_{3}\right.$ requires: $\mathrm{C}, 70.18 ; \mathrm{H}, 4.77 ; \mathrm{N}, 11.69$. Found: C. 69.96; $\mathrm{H}, 4.22 ; \mathrm{N}, 11.54 \%$.) $\delta_{\mathrm{H}}$ (acetone) $2.86\left(3 \mathrm{H}, \mathrm{s}, \mathrm{N}-\mathrm{CH}_{3}\right) ; 3.74(1 \mathrm{H}$, $\mathrm{dd}, J=7.8,7.8, \mathrm{H}-\mathrm{b}) ; 4.77(1 \mathrm{H}, \mathrm{d}, J=7.8, \mathrm{H}-\mathrm{a}) ; 4.90(1 \mathrm{H}, \mathrm{d}$, $J=8.1, \mathrm{H}-\mathrm{c}) ; 7.12(3 \mathrm{H}, \mathrm{m}, \mathrm{ArH}$ and $\mathrm{CH}=\mathrm{CH}-\mathrm{Ph}) ; 7.28(5 \mathrm{H}, \mathrm{m}$, $\mathrm{ArH}) ; 7.61$ (2H, m, ArH); $7.70(1 \mathrm{H}, \mathrm{d}, J=16.0, \mathrm{CH}=\mathrm{CH}-\mathrm{Ph})$. $\delta_{\mathrm{C}}$ (acetone) $25.6\left(\mathrm{~N}-\mathrm{CH}_{3}\right) ; 58.6(\mathrm{C} 11 \mathrm{a}) ; 62.7(\mathrm{C} 11 \mathrm{~b}) ; 80.1(\mathrm{C} 8 \mathrm{a})$; $119.1(\mathrm{CH}=\mathrm{CH}-\mathrm{Ph}) ; 125.4(\mathrm{ArC}) ; 127.4(\mathrm{ArCH}) ; 127.7(\mathrm{ArCH})$; 128.4 (ArCH); 128.9 (ArC); 129.1 (ArCH); 130.2 (ArCH); 130.8 $(\mathrm{ArCH}) ; 130.8(\mathrm{ArCH}) ; 137.0(\mathrm{ArCN}) ; 140.3(\mathrm{CH}=\mathrm{CH}-\mathrm{Ph})$; $157.2(\mathrm{~N}=C \mathrm{~N}) ; 171.9(\mathrm{C}=\mathrm{O}) ; 174.8(\mathrm{C}=\mathrm{O}) . \quad \mathrm{IR}: v=1712.7$ $(\mathrm{C}=\mathrm{O}) ; 1630.0(\mathrm{C}=\mathrm{C}) ; 1556.8(\mathrm{C}=\mathrm{N})$. NOEDS results for $\mathbf{1 2}$ : irradiation of $\mathrm{H}-\mathrm{c}$ caused a $6.3 \%$ enhancement on $\mathrm{H}-\mathrm{b}$; irradiation of $\mathrm{H}-\mathrm{a}$ caused enhancements on $\mathrm{H}-\mathrm{b}(3.1 \%)$ and on $\mathrm{ArH}(2.8 \%)$, irradiation of $\mathrm{H}-\mathrm{b}$ caused the following enhancement, $7.3 \%$ on H-c.

11 (0.16 g, 54\%), yellow solid, mp 110-112 ${ }^{\circ} \mathrm{C}$ (hexane-ether). $\delta_{\mathrm{H}}$ (acetone) $2.47\left(3 \mathrm{H}, \mathrm{s}, \mathrm{N}-\mathrm{CH}_{3}\right) ; 3.95(1 \mathrm{H}, \mathrm{dd}, J=7.1,7.5, \mathrm{H}-$ b); $4.95(1 \mathrm{H}, \mathrm{d}, J=7.5, \mathrm{H}-\mathrm{a}) ; 5.06(1 \mathrm{H}, \mathrm{d}, J=7.1, \mathrm{H}-\mathrm{c}) ; 6.93$ $(1 \mathrm{H}, \mathrm{d}, J=15.6, \mathrm{CH}=\mathrm{CH}-\mathrm{Ph}) ; 7.05(2 \mathrm{H}, \mathrm{m}, \mathrm{ArH}) ; 7.25(5 \mathrm{H}, \mathrm{m}$, $\mathrm{ArH}) ; 7.49$ (2H, m, ArH); 7.57 (1H, d, $J=15.9, \mathrm{CH}=\mathrm{CH}-\mathrm{Ph})$. $\delta_{\mathrm{C}}$ (acetone) $25.3\left(\mathrm{~N}-\mathrm{CH}_{3}\right) ; 54.9(\mathrm{C} 11 \mathrm{a}) ; 62.9(\mathrm{C} 11 \mathrm{~b}) ; 79.7(\mathrm{C} 8 \mathrm{a})$; $119.2(\mathrm{CH}=\mathrm{CH}-\mathrm{Ph}) ; 123.3(\mathrm{Cla}) ; 126.9(\mathrm{ArCH}) ; 127.4(\mathrm{ArCH})$; $128.9(\mathrm{ArCH}) ; 129.1(2 \times \mathrm{ArCH}) ; 130.1(2 \times \mathrm{ArCH}) ; 130.6$ $(\mathrm{ArCH}) ; 130.7(\mathrm{ArCH}) ; 137.2(\mathrm{ArC}) ; 139.5(\mathrm{CH}=\mathrm{CH}-\mathrm{Ph}) ; 141.5$ (C4a); 157.5 (C6); $173.3(\mathrm{C}=\mathrm{O})$. IR: $v=1712.7(\mathrm{C}=\mathrm{O}) ; 1630.0$ $(C=C) ; 1556.8(C=N)$. NOEDS results for 11: irradiation of $\mathrm{H}-\mathrm{c}$ caused a $6.2 \%$ enhancement on $\mathrm{H}-\mathrm{b}$; irradiation of $\mathrm{H}$-a caused enhancements on $\mathrm{H}-\mathrm{b}(6.3 \%)$ and on $\mathrm{ArH}(4.6 \%)$, irradiation of $\mathrm{H}-\mathrm{b}$ caused the following enhancements, $6.9 \%$ on $\mathrm{H}-\mathrm{c}$ and $6.8 \%$ on $\mathrm{H}-\mathrm{a}$.

$13 \delta_{\mathrm{H}} 3.11\left(3 \mathrm{H}, \mathrm{s}, \mathrm{N}-\mathrm{CH}_{3}\right) ; 5.28(1 \mathrm{H}, \mathrm{s}, \mathrm{CH}) ; 6.90(1 \mathrm{H}, \mathrm{d}$, $J=14.5, \mathrm{CH}=\mathrm{CH}-\mathrm{Ph}) ; 7.34(4 \mathrm{H}, \mathrm{m}, \mathrm{ArH}) ; 7.56(5 \mathrm{H}, \mathrm{m}, \mathrm{ArH}$ and $\mathrm{CH}=\mathrm{CH}-\mathrm{Ph}), 8.40(1 \mathrm{H}, \mathrm{d}, J=8.3, \mathrm{ArH}) ; 13.00(1 \mathrm{H}$, br s, $\mathrm{NH} / \mathrm{OH}) . \delta_{\mathrm{C}} 24.3\left(\mathrm{~N}-\mathrm{CH}_{3}\right) ; 68.2(\mathrm{CH}) ; 77.2(\mathrm{CH}=\mathrm{CH}-\mathrm{Ph}) ; 127.3$, 127.9, 128.0, 129.0, 130.1, 134.1 ( $9 \mathrm{x} \mathrm{ArCH}$ and $\mathrm{CH}=\mathrm{CH}-\mathrm{Ph})$; 118.1 (ArC); 121.1 (C1a); 127.7 (C4a); 128.8 (C6); 137.4 (C$\mathrm{C}(\mathrm{O})) ; 149.2(\mathrm{C}-\mathrm{OH}) ; 173.1(\mathrm{C}=\mathrm{O}) ; 175.7(\mathrm{C}=\mathrm{O}) . \mathrm{IR}: v=3424.7$ $(\mathrm{OH} / \mathrm{NH}) ; 1749.2(\mathrm{C}=\mathrm{O})$.

\section{5-[(E)-2-phenylethenenyl]-1-(phenylsulfonyl)-1,10b-dihydro-2 $H$ - isoxazolo[2,3-c]quinazoline, 14}

A solution of $1 \mathrm{a}(0.2 \mathrm{~g}, 0.81 \mathrm{mmol})$, and phenyl vinyl sulfone $(0.22 \mathrm{~g}, 1.62 \mathrm{mmol})$ was heated at reflux in dry THF $\left(30 \mathrm{~cm}^{3}\right)$ for $24 \mathrm{~h}$. The THF was removed under reduced pressure and the crude mixture was purified by flash column chromatography $\left(\mathrm{SiO}_{2}\right.$, hexane-ether, $\left.7: 3\right)$ to afford a yellow solid $(0.08 \mathrm{~g}, 49 \%$ based on \%nitrone consumption), $\mathrm{mp} 125-127^{\circ} \mathrm{C}$ (hexane-ether). $\left(\mathrm{C}_{24} \mathrm{H}_{20} \mathrm{~N}_{2} \mathrm{SO}_{3}\right.$ requires: $\mathrm{C}, 69.21 ; \mathrm{H}, 4.84 ; \mathrm{N}, 6.70 ; \mathrm{S}, 7.69$. Found: C, 68.87; H, 4.86; N, 6.65; S, 7.78\%.) $\delta_{\mathrm{H}} 3.73(1 \mathrm{H}, \mathrm{dd}, J=9.9$, 9.9, $\left.\mathrm{HC}-\mathrm{CH}_{2}-\mathrm{O}\right) ; 4.05(1 \mathrm{H}, \mathrm{m}, \mathrm{H}-\mathrm{c}) ; 4.42(1 \mathrm{H}, \mathrm{dd}, J=9.9,9.9$ $\left.\mathrm{HC}-\mathrm{CH}_{2}-\mathrm{O}\right) ; 5.22(1 \mathrm{H}, \mathrm{d}, J=6.7, \mathrm{Hd}) ; 6.99(1 \mathrm{H}, \mathrm{d}, J=16.0$, $\mathrm{CH}=\mathrm{CH}-\mathrm{Ph}) ; 7.11(1 \mathrm{H}, \mathrm{m}, \mathrm{ArH}) ; 7.32(5 \mathrm{H}, \mathrm{m}, \mathrm{ArH}) ; 7.57(4 \mathrm{H}$, $\mathrm{m}, \mathrm{ArH}) ; 7.69(1 \mathrm{H}, \mathrm{m}, \mathrm{ArH}) ; 7.76(1 \mathrm{H}, \mathrm{d}, J=16.0, \mathrm{CH}=\mathrm{CH}-$ $\mathrm{Ph}) ; 7.93(2 \mathrm{H}, \mathrm{m}, \mathrm{ArH}) . \delta_{\mathrm{C}} 59.3(\mathrm{Ph}-\mathrm{CH}-\mathrm{N}) ; 69.9\left(\mathrm{CH}_{2}\right) ; 74.0$ $(\mathrm{CH}, \mathrm{m}) ; 117.9(\mathrm{CH}=\mathrm{CH}-\mathrm{Ph}) ; 122.4(\mathrm{ArC}-\mathrm{CHd}) ; 126.4(\mathrm{ArCH})$; $126.4(\mathrm{ArCH}) ; 127.8(2 \times \mathrm{ArCH}) ; 127.9(\mathrm{ArCH}) ; 128.7(2 \times$ $\mathrm{ArCH}) ; 128.8(2 \times \mathrm{ArCH}) ; 129.5(\mathrm{ArCH}) ; 129.8(\mathrm{ArCH}) ; 129.8$ 
$(2 \times \mathrm{ArCH}) ; 134.6(\mathrm{ArCH}) ; 135.5(\mathrm{ArC}) ; 138.0(\mathrm{ArC}-\mathrm{N}) ; 139.3$ $(\mathrm{ArC}=\mathrm{N}) ; 139.6(\mathrm{CH}=\mathrm{CH}-\mathrm{Ph}) . \mathrm{IR}: v=3062.5(\mathrm{CH}=\mathrm{CH}) ; 1636.7$ $(\mathrm{C}=\mathrm{C}) ; 1559.0(\mathrm{C}=\mathrm{N})$; $1357.1\left(\mathrm{SO}_{2}\right)$. NOEDS results for $\mathbf{1 4}$ : irradiation of $\mathrm{H}-\mathrm{b}$ caused the following enhancements, $22.5 \%$ on $\mathrm{H}-\mathrm{a}, 6.4 \%$ on $\mathrm{H}-\mathrm{c}$ and $2.9 \%$ on $\mathrm{ArH}$; irradiation of $\mathrm{H}-\mathrm{c}$ caused enhancements on $\mathrm{Hd}(2.0 \%), \mathrm{H}-\mathrm{b}(3.8 \%)$ and on $\mathrm{ArH}(4.3 \%)$, irradiation of $\mathrm{H}$-a caused the following enhancements, $20.1 \%$ on $\mathrm{H}-\mathrm{b}, 1.1 \%$ on $\mathrm{Hd}, 0.6 \%$ on $\mathrm{H}-\mathrm{c}$ and $5.2 \%$ on $\mathrm{ArH}$; irradiation of Hd caused enhancements on H-c (1.8\%) and on $\mathrm{ArH}(7.2 \%)$.

\section{Methyl 2-[(E)-2-phenylvinyl]-5 $H$-1,3-benzodiazepine-5- carboxylate 17}

(i) From the reaction between 1c and dimethyl acetylenedicarboxylate following purification on (a) $\mathrm{SiO}_{2}$ or (b) $\mathrm{Al}_{2} \mathrm{O}_{3}$. (a) $\mathrm{A}$ solution of 2-[(E)-2-phenylvinyl]quinazoline-3-oxide 1c $(0.10 \mathrm{~g}$, $0.40 \mathrm{mmol})$ and dimethyl acetylenedicarboxylate $(0.12 \mathrm{~g}, 0.80$ $\mathrm{mmol}$ ) was allowed to stir at $\mathrm{rt}$ for $15 \mathrm{~min}$ in dry THF $\left(10 \mathrm{~cm}^{3}\right)$. The THF was removed under reduced pressure and the crude product was purified by flash column chromatography over $\mathrm{SiO}_{2}$ (hexaneether, $7: 3)$ to afford a yellow solid $(0.03 \mathrm{~g}, 20 \%), \mathrm{mp} 104-106{ }^{\circ} \mathrm{C}$ (hexane-ether). $\left(\mathrm{C}_{19} \mathrm{H}_{16} \mathrm{~N}_{2} \mathrm{O}_{2}\right.$ requires: $\mathrm{C}, 74.98 ; \mathrm{H}, 5.29 ; \mathrm{N}, 9.20$. Found: C, 74.37; H, 5.32; N, 8.95\%.) $\delta_{\mathrm{H}} 3.76\left(0.75 \mathrm{H}, \mathrm{s}, \mathrm{OCH}_{3}\right.$ taut); $3.79\left(2.25 \mathrm{H}, \mathrm{s}, \mathrm{OCH}_{3}\right.$ taut); $4.35\left(0.5 \mathrm{H}, \mathrm{s}, \mathrm{CH}_{2}\right.$ taut $) ; 5.50$ $(0.75 \mathrm{H}, \mathrm{s},=\mathrm{CH}-\mathrm{N}$ taut $) ; 6.86(0.75 \mathrm{H}, \mathrm{d}, J=16.3,=\mathrm{CH}) ; 7.36$ and $7.62(8.5 \mathrm{H}, 2 \times \mathrm{m}, \mathrm{ArH}$ and $=\mathrm{CH}$ taut $) ; 7.73(0.75 \mathrm{H}, \mathrm{d}, J=$ 7.5, ArCH taut); $7.85(0.25 \mathrm{H}, \mathrm{m}, \mathrm{ArH}$ taut $) ; 7.99(0.5 \mathrm{H}, \mathrm{m}, 2 \times$ ArH taut); $8.15(0.25 \mathrm{H}, \mathrm{d}, J=16.3,=\mathrm{CH}) ; 12.80(0.75 \mathrm{H}$, br s, $\mathrm{NH}$ taut $). \delta_{\mathrm{C}} 42.0\left(\mathrm{CH}_{2}\right.$ minor taut $) ; 51.3\left(\mathrm{OCH}_{3}\right.$ major taut $) ; 52.9$ $\left(\mathrm{OCH}_{3}\right.$ minor taut); 78.5 ( $=\mathrm{CH}-\mathrm{N}$ major taut); $122.3(\mathrm{CH}$ alkene major taut); 123.6, 126.5, 127.6, 128.1, 128.2, 128.4, 129.3, 129.4, 130.2, 135.5, 137.9, $139.1(9 \times \mathrm{ArCH}, \mathrm{CH}$ alkene major, $2 \times \mathrm{CH}$ alkene minor); 125.5, 129.2, 134.3 (3 $\times \mathrm{ArCH}$ taut); $119.6(\mathrm{C} 5 \mathrm{a}$ major); 135.4, 146.0, 149.5, 150.6, 151.3, 160.9 (ArC); 170.1, 171.2 $\left(2 \times \mathrm{CO}_{2} \mathrm{CH}_{3}\right)$. IR: $v=3080.9(\mathrm{NH}) ; 2940.7(\mathrm{CH}=\mathrm{CH}) ; 1750.9$ $\left(\mathrm{CO}_{2} \mathrm{CH}_{3}\right)$.

(b) The reaction was repeated with a three fold scale-up and the crude mixture was purified by column chromatography over $\mathrm{Al}_{2} \mathrm{O}_{3}$ (hexane-ether, $8: 2$ ) to afford the same yellow solid ( $0.03 \mathrm{~g}$, $7 \%)$.

(ii) From the reaction between $1 \mathrm{c}$ and methyl propiolate. A solution of $1 \mathrm{c}(0.20 \mathrm{~g}, 0.81 \mathrm{mmol})$ and methyl propiolate $(0.13 \mathrm{~g}$, $1.62 \mathrm{mmol})$ was heated at reflux in dry $\operatorname{THF}\left(25 \mathrm{~cm}^{3}\right)$ for $2 \mathrm{~h}$. The THF was removed under reduced pressure and the crude reaction mixture was purified by flash column chromatography $\left(\mathrm{SiO}_{2}\right.$, hexane-DCM, $\left.7: 3\right)$. Two products were isolated. Firstly, methyl 1-[(E)-3-phenyl-2-propenoyl]-1 $H$-indole-3-carboxylate 18, a white solid, $(0.01 \mathrm{~g}, 5 \%), \mathrm{mp} 108-110{ }^{\circ} \mathrm{C} .\left(\mathrm{C}_{19} \mathrm{H}_{15} \mathrm{~N}_{1} \mathrm{O}_{3}\right.$ requires C, 74.74; H 4.95; N, 4.59. Found C, 70.10; H, 4.71; N, 4.18\%.) $\delta_{\mathrm{H}} 3.98\left(3 \mathrm{H}, \mathrm{s}, \mathrm{OCH}_{3}\right) ; 7.10(2 \mathrm{H}, \mathrm{m},=\mathrm{CH}$ and $\mathrm{ArH}) ; 7.45(4 \mathrm{H}$, $\mathrm{m}, \mathrm{ArH}) ; 7.69(2 \mathrm{H}, \mathrm{m}, \mathrm{ArH}) ; 8.05(1 \mathrm{H}, \mathrm{d}, J=15.4,=\mathrm{CH}) ; 8.17$ $(1 \mathrm{H}, \mathrm{m}, \mathrm{ArH}) ; 8.37(1 \mathrm{H}, \mathrm{s}, \mathrm{CH}) ; 8.54(1 \mathrm{H}, \mathrm{m}, \mathrm{ArH}) . \delta_{\mathrm{C}} 116.1$ $(1 \times \mathrm{ArCH}$ and $=\mathrm{CH}) ; 116.7,121.7,124.9,125.9,128.6,129.2$, $131.3(7 \times \mathrm{ArCH}) ; 113.7(\mathrm{ArC}) ; 127.5(C=\mathrm{CH}) ; 130.6(\mathrm{CH})$; 134.1 (ArC-N); $136.3(\mathrm{Ar} C-\mathrm{C}=\mathrm{CH}) ; 148.3(=\mathrm{CH}) ; 164.3,164.3$ $(2 \times \mathrm{C}=\mathrm{O})$. The second product isolated was 17 , a yellow solid, $(0.02 \mathrm{~g}, 9 \%)$.
Table 3 Crystal data and structure refinement for $\mathbf{1 8}$

\begin{tabular}{ll}
\hline Identification code & $\mathrm{fhx}$ \\
Empirical formula & $\mathrm{C}_{38} \mathrm{H}_{30} \mathrm{~N}_{2} \mathrm{O}_{6}$ \\
Formula weight & 610.64 \\
Temperature & $293(2) \mathrm{K}$ \\
Wavelength & $0.71069 \AA$ \\
Crystal system & Triclinic \\
Space group & $P-1$ \\
Unit cell dimensions & $a=7.4430(10) \AA, a=82.95(2)^{\circ}$ \\
& $b=10.892(2) \AA, \beta=81.14(2)^{\circ}$ \\
& $c=19.212(3) \AA, \gamma=88.01(2)^{\circ}$ \\
Volume & $1527.1(4) \AA^{3}$ \\
$Z$ & 2 \\
Density (calculated) & $1.328 \mathrm{Mg} \mathrm{m}^{-3}$ \\
Absorption coefficient & $0.090 \mathrm{~mm}^{-1}$ \\
$F(000)$ & 640 \\
Crystal size & $0.35 \times 0.30 \times 0.20 \mathrm{~mm}$ \\
Theta range for data collection & 2.06 to $25.98^{\circ}$ \\
Index ranges & $-2 \Leftarrow h \Leftarrow 9 ;-13 \Leftarrow k \Leftarrow 13 ;$ \\
& $-23 \Leftarrow l \Leftarrow 23$ \\
Reflections collected & 7081 \\
Independent reflections & $5982[R($ int $)=0.0109]$ \\
Reflections observed $(>2 \sigma)$ & 3370 \\
Data completeness & 0.998 \\
Absorption correction & None \\
Refinement method & Full-matrix least-squares on $F^{2}$ \\
Data/restraints/parameters & $5982 / 0 / 417$ \\
Goodness-of-fit on $F^{2}$ & 1.053 \\
Final $R$ indices $[I>2 \sigma(I)]$ & $R_{1}=0.0410, w R_{2}=0.1190$ \\
$R$ indices (all data) & $R_{1}=0.0947, w R_{2}=0.1417$ \\
Largest diff. peak and hole & 0.212 and $-0.291 \mathrm{e} \AA^{-3}$ \\
&
\end{tabular}

$R$ indices; $R_{1}=\left[\Sigma\left\|F_{\mathrm{o}}|-| F_{\mathrm{c}}\right\|\right] / \Sigma\left|F_{\mathrm{o}}\right|$ (based on $\left.F\right), w R_{2}=\left[\left[\Sigma_{w}\left(\mid F_{\mathrm{o}}{ }^{2}-\right.\right.\right.$ $\left.\left.\left.F_{\mathrm{c}}{ }^{2} \mid\right)^{2}\right] /\left[\Sigma_{w}\left(F_{\mathrm{o}}{ }^{2}\right)^{2}\right]\right]^{1 / 2}$ (based on $\left.F^{2}\right) . w=1 /\left[\left(\sigma F_{\mathrm{o}}\right)^{2}+(0.0781 \times P)^{2}\right]$. Goodness-of-fit $=\left[\Sigma_{w}\left(F_{\mathrm{o}}{ }^{2}-F_{\mathrm{c}}{ }^{2}\right)^{2} /(N \text { obs }-N \text { parameters })\right]^{1 / 2}$.

X-Ray crystal determination of 18 . The structure was solved by direct methods, SHELXS-97, ${ }^{26}$ and refined by full matrix least squares using SHELXL-97. ${ }^{27}$ SHELX operations were automated using ORTEX which was also used to obtain the drawings. ${ }^{31}$ Data were corrected for Lorentz and polarization effects but not for absorption. Hydrogen atoms were included in calculated positions with thermal parameters $30 \%$ larger than the atom to which they were attached. The non-hydrogen atoms were refined anisotropically. All calculations were performed on a Pentium PC. There were two molecules per asymmetric unit. The unit cell and its contents were checked for any missed symmetry using the program CHKSYM and no missed symmetry was found..$^{28}$ The two independent molecules differed only by a minor change in conformation about the $\mathrm{N}(1)-\mathrm{C}(9)$ bond and a $180^{\circ}$ difference in conformation about the $\mathrm{C}(2)-\mathrm{C}(18)$ bond. Details of the data collection, solutions, and refinements are given in Table 3.

\section{References}

1 R. C. F. Jones and J. N. Martin, Synthetic Applications of 1,3-Dipolar Cycloaddition Chemistry Toward Heterocycles and Natural Products, ch. 1, Nitrones, in Chemistry of Heterocyclic Compounds, ed. A. Padwa and W. H. Pearson, Wiley, Chichester, United Kingdom, 2002, vol. 59, pp. 1-81.

2 U. Stauss, H. P. Haerter, M. Neuenschwander and O. Schindler, Helv. Chim. Acta, 1972, 55, 771-780.

3 E. Georgescu, I. Druta and M. Petrovanu, Rev. Roum. Chim., 1981, 26, 109-116.

4 E. I. Georgescu, F. Georgescu, M. G. E. G. Gheorghiu and M. Petrovanu, Rev. Roum. Chim., 1985, 30, 611-615. 
5 (a) F. Heaney and E. Lawless, J. Heterocycl. Chem., submitted; (b) M. Akazome, J. Yamamoto, T. Kondo and Y. Watanabe, J. Organomet. Chem., 1995, 494, 229-233.

6 A. K. Sharma, G. Hundal, S. Obrai and M. P. J. Mahajan, Chem. Soc., Perkin Trans. 1, 1999, 615-620.

7 C. W. Bird and G. W. H. Cheeseman, J. Chem. Soc., 1962, 3037-3040.

8 J. P. Freeman, Chem. Rev., 1983, 83, 241-261.

9 Y. Ishiguro, M. Yoshida, K. Funakoshi, S. Saeki, M. Hamana, I. Ueda and S. Kawano, Heterocycles, 1976, 5, 255-260.

10 H. Yamanaka, S. Niitsuma, T. Sakamoto and M. Mizugaki, Heterocycles, 1983, 20, 193-196.

11 T. Zujewska and B. Bachowska, Aust. J. Chem., 1996, 49, 523-525.

12 E. Oishi, H. Yamamoto and E. Hayashi, Yakugaku Zasshi, 1981, 101, 1042-1048, (CA 96:199611).

13 H. S. Kim, Y. Kurasawa and A. Takada, J. Heterocycl. Chem., 1989, 26, 871-873.

14 E. Malamidou-Xenikaki and E. Coutouli-Argyropoulou, Tetrahedron, 1990, 46, 7865-7872.

15 M. Kuzaj, H. Luerssen and C. Wentrup, Angew. Chem., Int. Ed. Engl., 1986, 98, 476-477.

16 H. Yamanaka, S. Niitsuma, T. Sakamoto and M. Mizugaki, Chem. Pharm. Bull., 1979, 27, 2291-2294.

17 J. Kurita, M. Enkaku and T. Tsuchiya, Heterocycles, 1983, 20, 2173 2176.

18 J. Kurita, T. Iwata, S. Yasuike and T. Tsuchiya, Chem. Commun., 1992, $81-82$.
19 P. Molina, A. Arques, A. Alias, M. V. Vinader, M. C. FocesFoces and F. Hernandez-Cano, Tetrahedron, 1992, 48, 30913110.

20 P. Molina, A. Arques, A. Alias and M. V. Vinader, Tetrahedron Lett., 1991, 32, 4401-4404.

21 A. Reisinger, R. Koch, P. V. Bernhardt and C. Wentrup, Org. Biomol. Chem., 2004, 2, 1227-1238.

22 M. Abdul-Ghani, S. H. A. Benomar and A. E. Tipping, J. Fluorine Chem., 1994, 69, 171-183.

23 A. Liguori, R. Ottana, G. Romeo, G. Sindona and N. Uccella, Tetrahedron, 1988, 44, 1247.

24 P. Molina, A. Arques, M. L. Garcia and M. V. Vinader, Synth. Commun., 1987, 17, 1449-1457.

25 P. W. Manley, C. W. Rees and R. C. Storr, J. Chem. Soc., Chem. Commun., 1983, 1007-1008.

26 G. M. Sheldrick, Acta. Crystallogr., Sect. A: Found. Crystallogr., 1990, A46, 467.

27 G. M. Sheldrick, SHELXL-97, A computer programme for crystal structure determination, University of Gottingen, 1997.

28 P. McArdle, P. Daly and D. Cunningham, J. Appl. Crystallogr., 2002, 35, 378-378.

29 W. Kabsch, J. Appl. Crystallogr., 1993, 26, 795-800.

30 G. M. Sheldrick, SHELX-97, A computer program for refinement of crystal structures, University of Gottingen, Germany, 2004.

31 P. McArdle, J. Appl. Crystallogr., 1995, 28, 65. 